\title{
US-Taliban peace deal and regional powers as potential spoilers: Iran as a case study
}

\author{
Raj Verma ${ }^{1,2}$ (D)
}

Accepted: 11 May 2021 / Published online: 26 May 2021

(c) The Author(s), under exclusive licence to Springer Nature Limited 2021

\begin{abstract}
There is a broad consensus that the US-Taliban peace deal does not augur peace and stability in Afghanistan. However, most of the experts have ignored the role of regional powers and their interests and their impact on the US-Taliban peace deal. This paper explores the case of Iran as a potential spoiler and exacerbating violence and instability in Afghanistan. It discusses three reasons for Iran's intervention: the Taliban dominating the inclusive national unity government or trying to establish an Islamic Emirate through military force and Iran-Pakistan clash of interests, the continued persecution of Shias and Hazaras by the Taliban and worsening of USIran relations. It highlights the various tools especially the non-state actors at Iran's disposal to achieve its political, economic and strategic objectives in Afghanistan. It also analyses the potential constraints that might limit/inhibit Iran in meeting its foreign policy and security objectives in Afghanistan and the broader region.
\end{abstract}

Keywords US-Taliban peace deal · Afghanistan · Iran-pakistan · Hazara/Shia · Trump $\cdot$ Islamic state in Iraq and Syria

\section{Introduction}

On 29 February 2020, the US and the Taliban signed a peace deal in Doha, Qatar. According to the peace deal, the US will withdraw 5,400 troops and close five military bases in 135 days and the remaining 8600 troops will be withdrawn in 14 months. ${ }^{1}$ This is conditioned on the Taliban cutting ties with Al-Qaeda and other

\footnotetext{
${ }^{1}$ North Atlantic Treaty Organization (NATO) also decided to withdraw its troops although NATO is not a part of the peace deal.
}

Raj Verma

rajneeshverma2000@gmail.com

https://www.linkedin.com/in/raj-verma-676bb35/

1 Huaqiao University, No. 668, Jimei Avenue, Xiamen 361021, Fujian, China

2 Intellisia Institute, Guangzhou, China 
terrorist organizations and not allowing such terrorist organizations to operate and organize attacks against the US and its allies from territory under the group's control. The Taliban also agreed to enter into an intra-Afghan dialogue on $10 \mathrm{March}$ 2020 in Oslo, Norway. Both sides also agreed to a prisoner exchange with 5000 Taliban prisoners being released in exchange for 1000 Afghan security forces personnel, but withdrawal of troops is not linked to the prisoner exchange.

The conditional peace deal has been severely criticized by analysts and policy makers. They argue that the deal does not portend peace and stability in Afghanistan for multiple reasons. While some experts say the conditional peace deal is a facesaving device for the Trump administration (Strategic Comments 2019), others are of the opinion that the main purpose of the peace deal is to bring back US troops from Afghanistan. The deal is not to restore peace but an election gimmick to win the Trump voter base and ensure Trump's re-election. ${ }^{2}$ By pulling back troops, the Trump administration is 'at peace with war' in Afghanistan.

Most of the experts have ignored the role of regional powers and their interests in Afghanistan and how this may impact the US-Taliban peace deal and peace and stability in Afghanistan. In January 2009, General David Petraeus, the then commander of the US Central Command remarked, 'It's not possible to solve the challenges internal to Afghanistan without addressing the challenges, especially in terms of security, with Afghanistan's neighbours. A regional approach is required (Motwani and Bose 2015: 268). Iran and Pakistan have close relations with the Taliban. Both countries have provided aid, arms and ammunition, training and refuge to Taliban cadres and Taliban and Al-Qaeda leaders (Akbarzadeh and Ibrahimi 2020). Iran, India and Russia provided aid and arms and ammunition to the Tajik led Northern Alliance whereas Saudi Arabia, UAE and Pakistan aided the Taliban in Afghanistan's civil war after the Soviets withdrew in 1989. The regional players are not party to the US-Taliban deal. Iran and Pakistan can be spoilers and can exacerbate the poor security situation in Afghanistan and further destabilize the country. The peace deal completely ignores Iran's interest in Afghanistan. ${ }^{3}$ This paper explores the case of Iran, a regional power, as a potential spoiler and exacerbating violence and instability in Afghanistan if US troops do not withdraw from Afghanistan or the Taliban tries to establish an Islamic Emirate or becomes a dominant force in a national government in Afghanistan and continues to persecute the Shia and Hazara.

The paper proceeds as follows. First, the paper discusses the existing literature on spoilers and their utilization in the context of Afghanistan. Next it discusses Iran's

\footnotetext{
2 Trump made an election pledge to bring back US troops. He wants to fulfil his pledge and bring back US troops before the presidential elections in November 2020. He is not concerned whether the Taliban re-forms an Islamic Emirate in Afghanistan or civil war ensues in Afghanistan after the US withdrawal (Barton 2020; Kube and Lee 2019).

3 Iran was not party to the ten rounds of negotiations before the deal was signed. It was also not present at the time of signing the deal when other countries such as Indonesia, Turkey and others were present. Therefore, Iran has held extensive talks with the Taliban regarding the US-Taliban peace deal. A second round of talks were held in Tehran in December 2019. In December 2019, Iran hosted a 'regional security dialogue' conference attended by the National Security Advisors from Iran, Uzbekistan, Afghanistan, Russia and India.
} 
multi-faceted political, security, economic and developmental interests in Afghanistan. There is a consensus that Iran is following a 'developmental' approach in Afghanistan to achieve its political and security objectives. This is followed by a discussion of the reasons why Iran can be a spoiler. I argue there are three reasons: the establishment of or attempts to establish an Islamic Emirate in Afghanistan by the Taliban (leading to a civil war in the country) or Taliban dominating the inclusive national unity government and clash of interests between Iran and Pakistan, continued persecution of Shias and Hazaras by the Taliban either under an Islamic Emirate or as a part of the government in Afghanistan and worsening of US-Iran relations. This is followed by an analysis of how Iran can jeopardize peace and security in Afghanistan. This section discusses the various tools especially the non-state actors (NSAs) at Iran's disposal such as Shia and Hazara fighters from Afghanistan and Tajik, Uzbek and other militias and warlords which Iran supported in the civil-war in Afghanistan. It also highlights the potential constraints that might limit/ inhibit Iran in supporting its proxy forces and meeting its foreign policy objectives in Afghanistan and the broader region.

\section{The spoiler typology}

The genesis of spoiler typology can be traced to the pioneering work of Stedman (1997). Stedman studies the role of spoilers in undermining a peace agreement. He defines spoilers as 'leaders and parties who believe that peace emerging from negotiations threatens their power, worldview, and interests, and use violence to undermine attempts to achieve it' (Stedman 1997: 5). Stedman classifies spoilers into three types based on their goals and their commitments to achieve these goalstotal, greedy and limited-with limited and total spoilers at the opposite end of the spectrum and greedy in the middle.

Total spoilers are those who have irreversible preferences and pursue exclusive recognition of authority and absolute power. Their leaders suffer from pathological tendencies which prevents them from making compromises to achieve peace and drives them to achieve maximalist goals. Total spoilers are likely to embrace radical ideologies and are willing to espouse violence to completely transform the society. Limited spoilers at the other extreme have limited goals such as sharing power, redressing a grievance and recognition among other goals. However, they are willing to accept heavy sacrifice to achieve their goals and their commitment is non-negotiable. The greedy spoilers may have total and limited goals. Limited goals expand when associated risks and costs are low. On the other hand, its total goals contract in the face of high risks and costs (Stedman 1997).

Motwani and Bose (2015) have employed Stedman's typology of spoilers in the context of Afghanistan. They categorize spoilers in Afghanistan based on their goals and their commitment to achieve their goals. They define limited spoilers as external actors whose national interests largely converge with Kabul's national goals. They also have differences with Kabul and it might be difficult to reach a consensus at the bilateral level necessitating intervention in Afghanistan's sovereign affairs. However, there is enough room to reach an amicable solution with the Afghan government. 
On the other hand, total spoilers have goals and interests which are at complete odds with Kabul and there can be no reconciliation between the two sides. The best solution to the problem of total spoilers is their total defeat (using military means or otherwise) or marginalization to an extent where their ability to cause harm is minimized (ibid.).

Greedy spoilers have a limited or weak convergence with Kabul's interests and objectives and are opposed to some goals. Such spoilers can be co-opted if they are presented with high costs and risks relating to their objectives or if their contrary interests are met. Tackling greedy spoilers is a challenging task. It necessitates that a state possesses a strong, competent and resilient military force to withstand the high costs associated with an armed conflict and is able to convey a convincing threat to the hostile and aggressive forces. Motwani and Bose (2015) classify Iran, Russia and India as limited spoilers, Pakistan as a greedy spoiler and the Taliban as a total spoiler. $^{4}$

\section{Iran's interests in Afghanistan}

Iran and Afghanistan have had historical and cultural relations. The Persian empire annexed several parts of Afghanistan's territory over a period of centuries. The two countries have also enjoyed religious and linguistic ties. The Pashtun majority in Afghanistan speak Pashto/Pashtu, one of the East Iranian languages. While the Tajiks speak a dialect of Persian called Dari, the Hazaras speak a Persian dialect called Hazaragi. Approximately $20 \%$ of the population of Afghanistan is Shia including the Hazaras, and Iran considers itself as the 'Guardian of Shia's across the globe' (Barzegar 2014).

Iran has four non-negotiable political, economic, security and strategic interests in Afghanistan. First, Iran wants a pro-Iranian government in Kabul. Iran aspires to create a Shia sphere of influence stretching from the Middle East into Central Asia via Afghanistan. This is to counter the spread of Wahabi/Sunni Islam propagated by Saudi Arabia ${ }^{5}$ (and UAE and Pakistan), and also to increase its influence in Central Asia. ${ }^{6}$ A constant in Iran's foreign policy is to have a robust and active political security presence in its neighbourhood to forestall future security problems. It wants to enhance its relative security in the broader region through a secure and stable

\footnotetext{
${ }^{4}$ For a detailed analysis of the rationale for the classification of the countries in different spoiler categories, see Motwani and Srinjoy Bose (2015).

5 For Iran-Saudi Arabia rivalry see Hiro (2018) and Ghattas (2020)

6 Iran has been an observer in the Shanghai Cooperation Organization (SCO) since 2005. Iran's membership to the SCO was rejected in 2010 because it was under UN sanctions. SCO was concerned about Iran's overly antagonistic outlook towards the US and its impact on their relations with the US. They do not want the SCO to be an evidently anti-US organization. Uzbekistan and Kazakhstan also object to Iran's membership because they perceive Iran as a source of Islamic militancy. The secular Central Asian countries believe that Iran's use of religion will have a destabilizing effect on their populace. For a more detailed discussion, see Akbarzadeh (2015).
} 
Afghanistan. It is to this end that Tehran wants an inclusive and pluralistic national unity government in Kabul favorable towards Iran (Barzegar 2014).

Since 2001, Iran has continued to provide political and diplomatic support to the Afghan government, and supported measures to increase state capacity to bring stability in Afghanistan. Iran is one of the largest regional investors in the country. In 2017-2018, it was Afghanistan's largest trading partner with bilateral trade exceeding US\$2 billion (The Financial Tribune 2018). Instability in Afghanistan will lead to a rise in terrorism and extremism in the region and beyond as witnessed in the past, and the re-emergence of the Taliban. Iran is aware that Afghanistan became a terrorism hub when the Taliban were in power from 1996-2001. Therefore, it does not want a Taliban led or dominated government in Kabul or the establishment of an Islamic Emirate by the Taliban. It is apprehensive that an Islamic Emirate or Sunni/ Wahabi Afghanistan will become a launchpad for anti-Iran activities (Kutty 2014).

Second, Iran considers Afghanistan as the focal point of its 'Look to the East' grand strategy. This strategy aims to establish close energy and economic ties with countries in East Asia and South Asia especially China, Japan and India. Iran plans to use Afghanistan as a conduit for supplying oil and gas to China, India and other countries. To achieve this, a stable Afghanistan is essential. This policy will also aid Iran in stabilizing Central Asia and South Asia especially Afghanistan through economic integration (Barzegar 2014; Akbarzadeh 2015; Samaan 2018). Iran also seeks a favorable transit route to Europe and Central Asia. It wants to be an indispensable partner in regional integration and to increase its economic influence in the region and beyond, and also develop and diversify its economy (Kutty 2014).

Iran has for long advocated that Afghanistan must have unfettered land and sea access to Central Asia and beyond for trade and commerce. This includes preserving trade and investment it has made in western Afghanistan especially in Herat (Milani n.d.), and trade through the port of Chabahar and gas pipelines in the future. To protect its economic interests, Iran has resisted development initiatives in Afghanistan that are outside the context/ambit of Iran-Afghanistan relations. For instance, the Tajikistan-Afghanistan-Pakistan-India pipeline and network of roads and railways linking India with Central Asia via Iran (Kuty 2014). Economic development will increase Iran's material resources and will aid Iran in becoming a great regional power, in its quest for leadership of the Islamic world vis-à-vis Saudi Arabia and expelling the US from the Middle East.

Third, Iran also wants to safeguard Iranians working in different capacities in Afghanistan. Iran is aware of the killing of eight Iranian diplomats and an Iranian journalist by the Taliban, and the group taking 50 Iranian citizens as hostages when they captured Mazar-i-Sharif in 1998. Iran amassed quarter of million troops along the border with Afghanistan and planned to invade the country. However, it backed down after UN intervention. It also has reservations against the persecution of ethnic and religious minorities in Afghanistan such as the Hazaras, the Tajiks and the Farsiwan Heratis-either by the Taliban or the Afghan government. It has supported Shia in Afghanistan and provided scholarships and funding for technical institutes for the 
Hazaras. ${ }^{7}$ It has also provided financial support for the construction of mosques in Herat and pro-Iranian seminaries in Kabul (Kuty 2014).

Since 2001, Iran has maintained close ties with key players in Afghanistan's politics. For instance, Abdullah Abdullah, the presidential rival of incumbent Ghani and the CEO (equivalent to the Prime Minister) in the previous Afghan government, Ismail Khan, the former governor of Herat and Minister of water and energy from 2005-2013, Mohammad Yunus Qanooni, the political and military heir of Ahmad Shah Masood (the legendary Tajik commander of the Northern Alliance) and former speaker of the lower house and others (Kuty 2014; Katzman 2020). According to diplomatic cables published by Wikileaks in 2009, Iran provided cash payments to 44 members of the Afghan parliament (Therme 2017). There are also reports that Iran provided cash payments to the Karzai regime to promote its interests in the Presidential palace. The funds were used by President Karzai to pay Taliban commanders, tribal elders and Afghan lawmakers to obtain their loyalty (Filkins 2010). Iran has created and employed Shia paramilitary units (especially drawing from the Hazara community) in various battlefields in the Middle East. Afghan Shia units have fought alongside other Iran supported Shia paramilitary units in the civil war in Syria (Mashal and Faizi 2017).

Fourth, Iran does not want the presence of US and NATO troops in Afghanistan. It feels encircled by the US and its allies in the Persian Gulf and also on the border in the east with Afghanistan. Presence of US forces in Afghanistan is a threat to Iran's national security and exacerbates its security dilemma. ${ }^{8}$ Iran perceives the US' presence in Afghanistan as US' attempts to increase influence in Central Asia and South Asia and bring instability into Iran. It perceives that the US' policies will undermine Iran's legitimate interests in Afghanistan and impede the re-establishment of close economic and political ties between Iran and Afghanistan. Iran has continued to criticize the US-Afghanistan Strategic Partnership Agreement signed in July 2012 and a Bilateral Security Agreement (BSA) signed in September 2014 between Afghanistan and the US (Katzman 2020; Akbarzadeh and Ibrahimi 2020). In November 2019, Seyyed Rasoul Mousavi, special assistant to Iran's Foreign Minister and Director General of the Southeast Asian Department of Iran's Ministry of Foreign Affairs, asked the US to cancel the US-Afghanistan BSA (Afghan Voice Agency n.d.). ${ }^{9}$ Iran fears that with US-Afghanistan security cooperation, Afghanistan will no longer be a neutral actor in the political affairs of Central Asia and South Asia which is detrimental for Iran. Iran continues to see the presence of

\footnotetext{
7 In 2017, there were 17,000 Afghan students studying for higher education in Iran (Ashrafi 2018). Universities in Iran have also opened branches in Herat and other cities in Afghanistan (Sawahel 2017).

8 Although the defeat and destruction of the Taliban by the US and NATO forces is beneficial for Iran, it considers the presence of foreign troops in Afghanistan as a bigger national security threat. It also believes that the presence of foreign troops has increased extremism in the region (Barzegar 2014).

9 In the past, Iran has criticized attempts by Afghanistan and the US to sign a bilateral security agreement. Iran has signed a bilateral strategic partnership agreement with Afghanistan which not only covers mutual security interests but also extends to other spheres. Iran has also criticized the presence of US troops in Iraq and has used its proxies in Iraq's legislature to expedite the removal of all foreign forces from the country (Tarzi 2020).
} 
foreign troops in Afghanistan as a major cause for the insurgency in the war-ravaged country (Kutty 2014; Barzegar 2014).

In addition to its non-negotiable strategic interests, Iran would also prefer a peaceful and secure Afghanistan which is inconspicuous to its neighbours. It does not want great power competition and protracted violence or insurgency in Afghanistan which will lead to mass migration of refugees into Iran. There are approximately one million Afghan refugees and an additional 2.5 million Afghans residing in Iran (UNHCR n.d.). This acts as a big drain on Iran's resources and increases socio-economic strife in the country. Iran has taken steps to facilitate the repatriation of refugees from Afghanistan who have faced discrimination and severe economic distress due to the US' economic sanctions. The refugee issue has led to tensions between the two countries. ${ }^{10}$

Last but not the least, Iran is extremely concerned about narcotics trade and the associated criminal and mafia activities. Iran is one of the leading countries in the world in combating narcotics trade and has spent US\$700 million in the campaign. In 2019, Iran seized around 814,477 kg of narcotics. Thousands of Iran's security forces have been killed in the drug war. In 2019, there were 2,319 clashes with drug-traffickers and five Iranian anti-drug agents were killed (Tehran Times 2020). Iran has engaged in aggressive counter-narcotics measures by investing in eastern Afghanistan and in Herat to provide alternate means of livelihood. It has blamed the West especially the US for its failure to stop the cultivation of poppy in Afghanistan. It has also blamed the Taliban for poppy cultivation to finance its operations and using Iran as a transit route to smuggle narcotics into Europe. ${ }^{11}$

\section{Why Iran can be a spoiler?}

Analysts and policy makers are deeply concerned that the Taliban will not accept Afghanistan's democratic political system and not respect women's rights and religious and ethnic tolerance especially in the context of the Shia and the Hazara. They believe that the Taliban want to establish an Islamic Emirate and implement Sharia Law as they did in the past. In the most optimistic scenario, the Taliban might accept a democratic system, but they will behave as winners and will want to exert significant influence if not outright control in the inclusive national unity government (Allen 2020; Felbab-Brown 2020; Riedel 2020). The worst fears were reaffirmed when on 25 March 2020, during a speech to Taliban supporters in Baluchistan, Pakistan, Mullah Fazel, former top Taliban military commander and senior member of Taliban's negotiating team in Doha stated, 'The Amir or leader of [a future

\footnotetext{
${ }_{10}$ Iran has also used the refugees as a political tool. During Ahmadinejad's presidency, Iran threatened to expel the refugees if Afghanistan ever inked a strategic security pact with the US (Kutty 2014; Barzegar 2014).

11 However, Iran's Islamic Revolution Guards Corps (IRGC) Quds Force and Shia militias have also been blamed for drug trafficking (Akbarzadeh and Ibrahimi 2020).
} 
government] will be ours. There will be an Islamic Emirate, and there will be a system based on Shari'a [Islamic law]' (Siddique 2020).

The establishment of an Islamic Emirate by the Taliban by using military means or a national unity government dominated by the Taliban with little or no constraints from other Afghan factions is a threat to Iran's national security and is against its interests not only in Afghanistan but also in Central Asia. This will bring Iran in conflict with Pakistan (and some Arab countries in the Middle East), a key supporter(s) of the Taliban. Additionally, the continued persecution of Shia and the Hazara by the Taliban (either in an Islamic Emirate or in a national unity government) will most likely force Iran to intervene in Afghanistan. The deterioration in US-Iran relations (as evidenced under the Trump administration) ${ }^{12}$ and the heightening of tensions between the two countries in the Persian Gulf might force Iran to use its proxies against the US in Afghanistan. It might continue to use its proxies against the US in Afghanistan as long as US troops are in the country.

\section{Iran-Pakistan}

Pakistan was instrumental in the formation of the Taliban after the Soviets withdrew from Afghanistan. Pakistan's Army and Inter-Services Intelligence (Pakistan's premier intelligence agency), have provided arms, training, and political and diplomatic support to the Taliban and Al-Qaeda, a fact admitted by Pakistan's Prime Minister Imran Khan (Council on Foreign Relations (CFR) 2019). After the Taliban was overthrown, it provided sanctuary to Taliban and Al-Qaeda leadership, and most of the Taliban fighters found refuge in the tribal areas along the Afghanistan-Pakistan border. Pakistan seeks strategic depth in Afghanistan in its rivalry with India. ${ }^{13}$ To achieve its goals in Afghanistan, Pakistan has supported the Taliban, the Haqqani

\footnotetext{
12 Under the Trump administration, Iran-US ties have been negatively affected since the US withdrew from the 2015 multilateral nuclear deal in May 2018. The US imposed economic sanctions against Iran in November 2018 under its policy of "maximum pressure" with little or no diplomatic space for talks to deescalate tensions. Responding to the US policy, Iran has attacked oil tankers, a US drone, oil refinery in Saudi Arabia and killed a US private contractor and injured Iraqi and US soldiers in a military base in Kirkuk, Iraq. The bilateral relationship deteriorated further after the assassination of General Qassem Soleimani-the leader of the elite Quds Force of IRGC - in a drone attack on 3 January 2020 in Iraq. Soleimani played a crucial role in expanding Iran's influence in the Middle East and in recruiting Afghans to fight for President Assad in the Syrian civil war. To avenge his killing, Iran launched more than a dozen missiles on two US military bases in Iraq injuring more than 100 people. The US doubled down on economic sanctions in January 2020. Some analysts assert that in matters of war and peace, Soleimani was Iran's real foreign minister. Others assert that he was the second most powerful man in Iran after Khamenei. Therefore, Iran will undertake calculated attacks against the US to avenge Soleimani's killing.

13 India and Pakistan have a zero-sum approach to influence in Afghanistan. India is aware that terrorist attacks in Indian Kashmir increased substantially when the Taliban were in power in Afghanistan. On the other hand, Pakistan fears encirclement by India. The strengthening of India-Afghanistan ties has led Pakistan to conclude that they want to destabilize and disintegrate Pakistan, and this process will speed up once the US withdraws troops from Afghanistan. Pakistan's elite has always considered Afghanistan as its backyard and sphere of influence. Hence, it wants a pliant regime in Kabul favorable towards Pakistan to reduce India's influence in Afghanistan. For a detailed discussion and analysis see Fair (2014); Verma (2020b).
} 
network and other terror proxies including anti-India terrorist organizations such as Lashkar-e-Taiba, Jasih-e-Mohammad, Harkat-ul-Ansar, Hizbul Mujahideen and others (operating in India and Afghanistan which have links with the Taliban, the Haqqani network and Al-Qaeda) (Fair 2014; Verma 2020a).

Pakistan played a key role in opening up a channel for the US to contact the Taliban for talks. If the talks fail, Pakistan is well positioned to use the Taliban to influence events in Afghanistan. If the intra-Afghan dialogue is successful, Pakistan will still play a pivotal role to ensure the agreement is implemented in letter and spirit. Pakistan has never wavered from its policy of seeking strategic depth and a pliant regime in Afghanistan favorable to Pakistan. Hence, in all eventualities, Pakistan is best placed to meet its strategic and security objectives relative to other countries in the region.

Iran is aware of Pakistan's interests in Afghanistan and the strategies adopted by Pakistan to achieve its objectives. Iran has developed close ties with the Taliban to counter the US in Afghanistan. Additionally, there is a realization in Tehran that peace and stability cannot be restored in Afghanistan until the Taliban is part of the national government in Afghanistan. However, Tehran is completely against the formation of an Islamic Emirate in Afghanistan. It is also against a Taliban led/ dominated national unity government. It prefers a minimalist participation of the Taliban in the national unity government with other Afghan factions having the ability to constrain the group (Akbarzadeh and Ibrahimi 2020). Taliban's Wahabi/Salafi extremist version of Islam is a threat to Iran's ideology. The Taliban is anti-Shia and anti-Iran. The Taliban also negatively impact Iran's security and national interests. Iran never recognized the Taliban regime during 1996-2001, and even aided the US and other countries to topple the Taliban regime in 2001.

Pakistan's preference for the Taliban to be at the helm of affairs in Kabul puts Iran at odds with Pakistan. ${ }^{14}$ Also, in the last couple of years, Pakistan has shown a propensity to side with Saudi Arabia in the Saudi-Iran rivalry, a fact not lost on Iran. An influential Pakistan (via the Taliban or otherwise) in Afghanistan will undermine Iran's role and interests in Afghanistan and the wider region. (Barzegar 2014). This will in all likelihood force Tehran to intervene in Afghanistan and support other factions in Afghanistan especially the Tajiks, Uzbeks and the Hazaras which will lead to a civil war in the country, reminiscent of the civil war after the Soviet withdrawal in 1989.

Iran and Pakistan have had good political, security and economic relations (Barzegar 2014). ${ }^{15}$ However, there is a lack of trust between the two countries. They have border conflicts and have exchanged fire in the border areas. Iran has compromised Pakistan's sovereignty by undertaking 'hot pursuit' in Pakistani territory to destroy militant hideouts and killed Pakistani citizens (Basit 2018). It has also undertaken covert operations in Pakistan to support Shia who have been frequently attacked by Sunni terrorist organizations (Destradi 2015). Both countries blame each other for supporting NSAs to flame separatist tendencies in their respective

14 Pakistan had the best relations with Afghanistan when the Taliban were in power from 1996-2001.

15 Most importantly, Abdul Qadeer Khan, a Pakistani nuclear scientist sold nuclear technology to Iran. 
Baluchistan province. Pakistan has also been peeved by strengthening Iran-India ties (Basit 2018). It has blamed Iran for not acting against Baluch separatists operating from Iran. In April 2019, Pakistan's Foreign Minister Shah Mahmood Qureshi blamed Iran for the terrorist attack on a bus in Baluchistan which killed 14 Pakistani security personnel (Radio Free Europe Radio Liberty (RFERL) 2019). On 13 May 2020, General Qamar Bajwa, Chief of Pakistan's Army warned Iran not to interfere in the domestic affairs of the country and to take action against Baluch separatists based in Iran after six Pakistani soldiers were killed in a terrorist attack close to the Iran-Pakistan border (Ahmed 2020). This highlights the tensions and mistrust between the two countries (Rehman 2014). ${ }^{16}$

Iran has grave concerns regarding the Sunni/Salafi terrorist organizations (Taliban and Al-Qaeda supported by Pakistan) operating in Afghanistan and Pakistan and Islamic State in Iraq and Syria (Daesh) which have conducted attacks against Iran and Iranian interests in Afghanistan (Shams 2019). These organizations not only threaten the territorial integrity of Iran but also regional security and stability. Jundallah, a Sunni terrorist organization formed in 2003 and based in south-eastern Iran, has undertaken numerous attacks in Iran and killed and kidnapped civilians and soldiers especially from Iran's elite IRGC (Rehman 2014; Barzegar 2014). The group aims to fight for the rights of the Sunni Baluch people living in south-east of Iran who have faced religious and sectarian persecution in the country (Hardy 2010). ${ }^{17}$

Iran has openly blamed the US, Saudi Arabia, Israel and the Taliban for supporting Jundallah (Hardy 2010; Rehman 2014; Basit 2018). Iranian officials have also stated that Pakistan (on Saudi Arabia's insistence) has provided support to the organization but Iran has not confronted Pakistan over the issue (Rehman 2014; Basit 2018). Recently, Jaish al-Adl, a Salafi group which is alleged to have links with Al-Qaeda, has also undertaken terrorist attacks in Iran. ${ }^{18}$ Iran has warned Pakistan to take action against the group after a suicide attack in Sistan-Baluchistan province in Iran killed 27 members of the elite IRGC (Regencia 2019). It claims that both the groups are based in Baluchistan, Pakistan. ${ }^{19}$ Iran asserts that the two Baluch organizations, the Taliban and other terrorist organizations in Afghanistan use drug trafficking to fund their operations which leads to protracted violence and generates instability (Rehman 2014; Barzegar 2014). Tehran has also blamed Islamabad for the massacre of Shias in Pakistan by Sunni organizations such as LeJ, Sipah-eSahiba-Pakistan and Jundallah, ${ }^{20}$ (affiliated with the Tehrik-i-Taliban Pakistan (TTP)

\footnotetext{
${ }^{16}$ Iran and Pakistan have also collaborated with each other in suppressing Baluch separatist organizations.

17 However, some analysts assert that later the group aligned itself with anti-Shia organizations in Pakistan such as Lashkar-e-Jhangvi (LeJ) and also established contacts with Al-Qaeda. Al-Qaeda decided to support Jundallah in its operations against Iran (Rehman 2014).

18 Some analysts assert that Jaish-al-Adl is the successor of Jundallah (Barzegar 2014). Others believe it is an offshoot of Jundallah (Rehman 2014).

19 However, Pakistan has denied the existence of anti-Iran militants in Pakistan (Rehman 2014).

20 In July 2018, Jundallah affiliated with the TTP pledged allegiance to Daesh (The Express Tribune 2014). Daesh has been conducting attacks in Iran since 2017.
} 
and based in Pakistan) (Fair 2014; Shams 2019). The persistence of Baluch insurgency on both sides of Iran's border may lead to Iranian intervention which will undermine peace and stability in Afghanistan and the wider region.

\section{Shia in Afghanistan}

The Hazaras who are predominantly Shia $^{21}$ are the third largest ethnic group in Afghanistan after the Pashtuns and the Tajiks. They constitute approximately 15\% of the population of Afghanistan. It is the most marginalized and the poorest ethnic group. Thousands of Hazaras migrated to Iran after the Taliban came to power in 1996. The Taliban along with Daesh consider Shia Muslims as heretics. ${ }^{22}$ There is both an ethnic and religious dimension to the atrocities against the Hazara. In 1998, the Taliban perpetrated one of the worst massacres in the history of Afghanistan when they killed 2,000 ethnic Hazaras in Mazar-i-Sharif. ${ }^{23}$ Hundreds of Hazaras were also killed in 2000-2001 in Bamiyan Province in central Afghanistan (Alizada 2019).

In the 2018 Taliban offensive in Uruzgan Provinces, dozens of Hazara civilians were killed and 500 Hazara families were forced to leave their homes. In November 2018, in Taliban attacks in Jaghori and Malistan districts in Ghanzi Province, 67 Hazaras were killed and $60 \%-70 \%$ of the people living in the Hazara dominated districts were displaced (Alizada 2019). The group has also kidnapped and killed Hazaras in Ghazni Province for some time (Adili and van Bijlert 2018). The Taliban attacks led to a very swift and strong reaction from the Hazara community. This pressurized the Afghan government to take action. The Hazaras (especially in Kabul) raised money to buy weapons for the local Hazaras in Jaghori and Malistan, and Hazara militias from other areas also reached the districts to fight against the Taliban. This clearly indicates that the Hazaras do not trust the government and will take arms to protect themselves. Analysts assert that the Taliban had been planning for a long time to capture Hazara areas to increase their influence and revenues, and sow discord between the Hazaras and the Afghan government (Adili and van Bijlert 2018).

There are concerns that a return of the Taliban in Afghanistan's political system either as an Islamic Emirate or a dominant player in the national unity government

\footnotetext{
21 Some Hazaras are also Sunni and Ismaili.

22 Iran has downplayed or overlooked the Taliban's killing of Shia in Afghanistan because it wants the group to fight Daesh in Afghanistan. Iran has made attempts to highlight the difference between the Taliban and Daesh to its domestic audience through state-controlled media. Iran considers Daesh as a bigger threat than the Taliban though both have persecuted and killed Shia and Hazara in Afghanistan. The Taliban has tried to distance itself from Daesh's extreme sectarianism and has condemned Daesh's attacks on Shia's as attempts to sow discord between the Shia and the Sunni (Akbarzadeh and Ibrahimi 2020). The Taliban and the Daesh are rivals in Afghanistan but they have also cooperated in Afghanistan. For a detailed analysis, see Ibrahimi and Akbarzadeh (2020).

23 The Hazaras were a key part of Northern Alliance fighting the Taliban. They also played a key role in defeating the Taliban in the first battle of Mazar-i-Sharif in May-July 1997 and were responsible for killing thousands of Taliban soldiers. In 1998, as revenge killing, Taliban perpetrated the massacre of Hazaras in Mazar-i-Sharif (Ali 2020).
} 
due to the peace deal will again lead to mass killings. The Taliban have continued to conduct terrorist attacks and suicide bombings against the Hazara community. Additionally, if the Taliban are a part of the democratic political system, it will most likely not prevent attacks against Hazara rallies, shrines and mosques by Daesh (Zucchino and Faizi 2019). Thus, the US-Taliban peace deal will lead to repression rather than peace. The Hazara community will never accept Taliban rule. They have made rapid strides since 2001. The Hazaras are more liberal than the Taliban with majority of the girls attending school. More Hazara boys receive education relative to other ethnic groups (Bezhan 2018). The Hazara community has decided to take arms to protect themselves against the Taliban if the peace deal brings the latter into the government or the Taliban tries to establish an Islamic Emirate (Zucchino and Faizi 2019; Aljazeera 2021).

Recently, the Taliban have tried to build bridges with the Hazaras. It is trying to send a message that it is no longer against the community. On 22 April 2020, the Taliban appointed Maulvi Mahdi, a Hazara, as the head of Balkhab district in Sar-iPul, a Shia dominated area. Analysts perceive this as a diplomatic move on the part of the Taliban to attract support with the intra-Afghan dialogue in mind. They assert that the Taliban is trying to win legitimacy among other ethnic groups in Afghanistan and portray themselves as a national movement. The Hazara have also acknowledged the change in the politics and ideology of the Taliban (Mehsud 2020). Others assert that appointment of Mahdi is an attempt to woo Iran which supports the Taliban (Kumar 2020). The Taliban have been successful in co-opting people from the Tajik and Uzbek communities but have no influence over the Hazaras. The killings of Hazaras in Ghazni and Uruzgan Provinces belies Taliban's commitment towards establishing harmonious relations with the Hazaras (Adili and van Bijlert 2018). If the Taliban become a part of the coalition government or establish an Islamic Emirate, and attacks continue against the Hazaras, Iran-which views itself as the protector of Shias across the world-might be forced to intervene in Afghanistan. Pakistan and Saudi Arabia which support the Taliban will also get involved in the conflict thus turning Afghanistan into a battleground for regional rivals.

\section{Iran-US}

Iran along with Russia, India and Tajikistan backed the Tajik led Northern Alliance in the civil-war in Afghanistan. Iran welcomed the US and NATO invasion of Afghanistan and along with the Northern Alliance provided intelligence and military assistance to oust the Taliban. Tehran benefitted significantly from the overthrow of the Taliban regime and expanded political, diplomatic and economic relations with Kabul. US-Iran relations remained tense due to Iran's rising influence in the Middle East and its nuclear program. Bilateral relations hit the nadir when President George Bush included Iran along with North Korea and Iraq in the 'axis of evil' in January 2002. Bush also referred to Pakistan as the US' closest non-NATO ally which raised Iran's suspicions with respect to Pakistan and the US. The second Bush administration remained silent on Pakistan's support to the Talban but continued to charge Iran 
for supporting the group. The US views Iran's engagement in Afghanistan as a zerosum game and has tried to reduce Iran's political, security and economic engagement in Afghanistan (Barzegar 2014).

Iran has been suspicious of US troops in Afghanistan. It has been apprehensive that the US will use its presence in Afghanistan to project influence into Iran and Central Asia, and also drive a wedge between Iran and Afghanistan. Iran developed relations with the Taliban to keep the US troops away from Iran's borders. After the collapse of the Taliban in 2001, it provided refuge to families of Osama bin Laden and senior Al-Qaeda leaders fleeing from Afghanistan. It also provided training and sophisticated military equipment to some Taliban groups to combat the US and NATO troops. At the same time, Iran continued to provide political and diplomatic support and development assistance to the Afghan government (Akbarzadeh and Ibrahimi 2020).

After the emergence of Daesh in Afghanistan in 2015 and deterioration of relations with the US under the Trump administration, Iran-Taliban relations took a new dimension. It provided sanctuary to the group's leadership and cadres, aid and arms and ammunition to the Taliban to not only combat Daesh, but also the US and NATO troops. It even opened a liaison office for the Taliban in Zahedan and later in Mashhad which led to the establishment of the Mashhad Shura (council). ${ }^{24}$ In October 2016, it even supported a Taliban offensive in Farah City, the provincial capital of Farah Province, in which four Iranian commandos died. Iran has adopted a policy of 'forward defense' that is to fight Daesh in other countries before it threatens Iran. For a long time, Tehran rejected or downplayed the importance of its ties and influence over the Taliban. However, recently Iran has publicly accepted its links with the Taliban (Akbarzadeh and Ibrahimi 2020).

Iran has rejected the US-Taliban peace deal calling it illegitimate and a pretext for the US to legitimize the presence of its forces in Afghanistan. It has stated that true and lasting peace in Afghanistan can only come through intra-Afghan dialogue and if interests of Afghanistan's neighbours are taken into account (Reuters 2020). The Afghan government is concerned that US-Iran tensions will lead to a spike in violence in the region, and Afghanistan may become an arena for a US-Iran proxy war which will hinder the peace process. After General Qaseem Soleimani's (former head of IRGC-Quds Force) assassination, President Ghani announced Afghanistan's neutrality and stated that the country will not allow its territory to be used for strikes against a third country or in a regional conflict (Mashal 2020).

After Soleimani's death, Iran sought Taliban's help to increase the intensity of attacks against the US forces in northern and western Afghanistan. On 28 January 2020, Taliban allegedly claimed to have shot down a US-E11 surveillance aircraft reportedly carrying Central Intelligence Agency (CIA) official D'Andrea who oversaw CIA operations in Afghanistan, Iraq and Iran. The shooting down of the plane

${ }^{24}$ In 2017, Mashhad council controlled ten per cent of Taliban's forces in Afghanistan (Akbarzadeh and Ibrahimi 2020). 
was attributed to Iranian assistance (Bhatia 2020). ${ }^{25}$ There is a realization in the US that Iran may pose a serious threat to reduced US forces in Afghanistan and also hinder the Afghan Peace process (Middle East Online 2020).

Iran-US tensions were further exacerbated in April 2020 when Trump ordered the US Navy to 'shoot down' Iranian boats harassing US warships. On 23 April, General Hossein Salami, Commander in Chief of IRGC ordered the Iranian Navy to destroy any US ship 'that threatens the security of Iran's military or civilian shipping' (Marcus 2020). There were fears that war of words might lead to military action or accidental conflict which does not bode well for peace and security in the Middle East and Afghanistan.

Although analysts and experts are of the opinion that Iran-US relations might improve under the Biden administration, there are concerns that the bilateral relations will remain tense as long as Iran follows a revolutionary foreign policy, and the US tries to contain Iran's rise (especially Iran's attempts to acquire nuclear weapons) and continues to check Iran's expanding influence in the region. Domestic politics in Iran and the US might also negatively impact relations and prevent/delay the US from re-joining the nuclear deal. At this point in time, both sides are sending signals and trying to gauge each other. The deterioration in the bilateral relationship may also lead to tensions between the two countries in Afghanistan. ${ }^{26}$

\section{How can Iran be a spoiler in Afghanistan?}

After the fall of the Taliban in 2001, Iran has expanded its influence in Afghanistan. It has employed diplomatic, economic and military tools to meet its objectives and expand influence. Iran has primarily relied on soft power tools such as cultural diplomacy, information gathering, economic aid, trade, investment in business and infrastructure development. However, Iran can call upon significant military assets and instruments to intervene in Afghanistan and secure its interests. ${ }^{27}$

Iran through the IRGC recruited tens of thousands of Shia fighters when the civil war started in Syria in 2011. ${ }^{28}$ Since 2012/2013, Iran has recruited thousands of Hazaras and Afghans living in Iran and formed the Fatemiyoun Brigade. ${ }^{29}$ The Fatemiyoun have fought alongside Russian forces, the Syrian Army, other pro-Assad Syrian militias, the Hezbollah and the Zaynabiyoun Brigade (Jamal 2019). Estimates vary about the strength of the brigade with some sources claiming 5,000-20,000

\footnotetext{
${ }^{25}$ CIA has not confirmed whether D'Andrea has died or not. He cannot be seen in public either (Dozier 2020).

${ }^{26}$ Personal communication with analysts and experts based in Iran, the US, Afghanistan, Australia and other countries in February 2021 via LinkedIn, Zoom and email.

27 Iran is less influential in Afghanistan relative to Iraq, Syria and Lebanon. Iran also has less influence over its proxy forces in and from Afghanistan relative to Shia militias in Iraq, Syria and Lebanon.

28 Pakistani Shia were also recruited. They were primarily recruited because of persecution of Shias in Pakistan rather than for the Syrian civil war. More than 1,000 Pakistani's are fighting in Syria with the Zaynabiyoun Brigade (Gandhara 2017; Alfoneh 2018).

${ }^{29}$ Fatemiyoun means followers of Fatema Zhara, the daughter of Prophet Muhammad.
} 
fighters and others 40,000-60,000 fighters. ${ }^{30}$ It also includes veterans of the Abuzar Brigade, an Afghan Shia militia which fought alongside Iran in the Iran-Iraq war in the 1980s. Ismail Qaani, the new head of the elite IRGC Quds Force ${ }^{31}$ played a significant role in the formation of Fatemiyoun Brigade. He was also involved in providing military, financial and logistical support to the Northern Alliance which was fighting the Taliban in the 1990s. As the civil war in Syria has ebbed, the Shia fighters have returned to Iran and Afghanistan. According to Rahmatullah Nabil, the former head of National Directorate of Security, Afghanistan's main intelligence agency, approximately 2500-3500 fighters have returned to Afghanistan (Bezhan 2020). Another report states that 10,000 fighters have retuned (Hamidi 2019). Most of these fighters are settled in the Hazara dominated central Afghanistan and western Afghanistan bordering Iran (Bezhan 2020).

According to some analysts, Iran can use the battle-hardened Fatemiyoun militia to meet its objectives in Afghanistan (Juneau 2020; Hamidi 2019; Gannon 2019). Iran can use its proxies against the US troops stationed in Afghanistan and other US interests, the Taliban (if the group assumes power in Afghanistan and continues to persecute the Shia and the Hazaras) and Daesh (which considers Shia Muslims as its mortal enemy) (Clarke and Tabatabi 2020). According to Marine General Frank McKenzie, the top US commander for the Middle East, Iran can use its proxies against the US in Afghanistan and the wider region (Jamal 2019). IRGC-Quds Force can use the most elite members of the Fatemiyoun for covert operations and terrorist attacks in Afghanistan (Clarke and Tabatabi 2020). Some analysts assert that Iran has already started deploying Fatemiyoun fighters in Afghanistan ${ }^{32}$; it is making preparations for Taliban's return to power in a post-US Afghanistan. Arif Rahmani, a member of Parliament in Afghanistan says, if the Fatemiyoun organize themselves into an armed group, 'neither the government nor the Shia-Hazara community will be able to stop them' (Jamal 2019).

Iran can also fall back on other Hazara, Tajik and Uzbek militias which it had supported in Afghanistan in the 1980s-1990s (Bezhan 2020). In 1988, Iran formed the Hezb-e Wahdat-e Islami or Islamic Unity Party, an amalgamation of seven Shia groups fighting against the Soviets. It further strengthened the group and continued to support it in Afghanistan's civil war in the 1990s. Iran has continued to support the Northern Alliance which is a central part of the National Front, the opposition in the Afghan parliament. Iran can also use some Taliban groups to attack US interests

\footnotetext{
30 In 2015, it was upgraded from a brigade (teep) to an army (Lashkar) with approximately 40,00060,000 .

fighters (Jamal 2019; Hamidi 2019; Bezhan 2020).

31 Quds force has been most noticeable in Lebanon, Iraq, Syria, Yemen, Gaza strip (where it is backed by Hamas) and Afghanistan. It has been operating more or less throughout the Middle East.

32 According to Ali Yawar Adili, Country Director (Afghanistan) at the Afghan Analyst Network, reports regarding deployment of the Fatemiyoun in Afghanistan are incorrect. In April 2020, this issue was raised in Afghanistan's parliament and the security officials including the Director General of the National Directorate of Security, the national security and intelligence agency of Afghanistan confirmed that the Fatemiyoun is not active in Afghanistan (Personal communication 16 February 2021, Zoom).
} 
in Afghanistan if the US troops continue to be based in Afghanistan (Kuty 2014; Akbarzadeh and Ibrahimi 2020).

There is a broad consensus amongst experts and analysts interviewed by the author that Iran can use its proxies in Afghanistan to secure its interests. All the 15 experts interviewed agree that if the US and NATO troops stay in Afghanistan beyond the deadline, Iran will continue to extend support to the Taliban. Alex Vatanka, Senior Fellow and Director Iran Program at the Middle East Institute says, 'Iran will do things tactically when needed and provide arms to the Taliban. It can use the Taliban in its tit for tat against the US'. ${ }^{33}$ According to Nishank Motwani, Deputy Director of the Afghanistan Research and Evaluation Unit, 'If American forces remain in Afghanistan, Iran is likely to continue its current posture of building links with armed groups including the Taliban to act as a hedge that can be utilized should U.S. forces pose a threat to core Iranian interests in Afghanistan or Iranian territory itself' ${ }^{34}$ However, all the experts agree that Iran will not employ the Fatemiyoun against the US in Afghanistan if US troops stay in Afghanistan. Ali Yawar Adili states, 'Apart from the Taliban, Iran has no other force/militia to fight against the US. Deployment of the Fatemiyoun is impossible because Kabul is aligned with the US. Deploying the Fatemiyoun against the US will undermine Iran's interests in Afghanistan and alienate Tehran from Kabul'. ${ }^{35}$

All the interviewed experts are unanimous that a negotiated political settlement between Kabul and the Taliban before the US troops leave Afghanistan is the best option for peace and stability in Afghanistan. They are also unanimous that if the Taliban tries to establish an Islamic Emirate through military force, it will most likely lead to civil/proxy war in Afghanistan. 13 out of the 15 experts agree that in this scenario Iran will be forced to intervene in Afghanistan through its proxies (Hazara militias, Tajiks, Uzbeks and the Fatemiyoun). If the Taliban are able to establish an Islamic Emirate or become a dominant part of the national unity government, and there is continued persecution of the Hazara and Shia by the Taliban, 13 out of the 15 experts believe Iran will arm the Shia militias (it may also deploy the Fatemiyoun).

According to Alex Vatanka, 'Iran can launch Fatemiyoun on Afghan soil and it will be an entity that Iran will have more control over than they had in the 1990s with the Shia militias'. ${ }^{36}$ Mahmoud Pargoo, Research Fellow at the Alfred Deakin Research Institute for Citizenship and Globalization, Deakin University believes, 'Iran has many cards to play in Afghanistan. Fatemiyoun is one and its relations with Iran are extremely strong. Logistically it will be easy for Iran. Fatemiyoun will be the most powerful Iran proxy in Afghanistan'. ${ }^{37}$ According to Mohsen Shariatinia, Assistant Professor of International Relations, Shahid Beheshti University, 'Iran understands that main thinking of Taliban on Shia has not changed in recent

\footnotetext{
33 Personal communication 15 February 2021, Zoom.

34 Personal communication 18 February 2021, Email.

35 Personal communication 16 February 2021, Zoom.

36 Personal communication 15 February 2021, Zoom.

37 Personal Communication 17 February 2021, Zoom
} 
years. Iran will support the Tajik, Uzbek and other militias if the Taliban becomes dominant. It will support the new Northern Alliance. The role of Fatemiyoun will be to defend the Hazara rather than reshape political order in Afghanistan'. ${ }^{38}$ Omar Samad, Senior Advisor to Abdullah Abdullah and non-resident Senior Fellow at the Atlantic Council believes, 'If the Taliban assumes full control and establishes an Islamic Emirate and Shia minorities are being targeted, then countries like Iran will revert to proxy warfare. Iran will have to rely on every proxy, maybe they have the Fatemiyoun at one level and on the other hand the traditional bits and pieces of what you call the Northern alliance'. ${ }^{39}$

\section{Factors inhibiting Iran's deployment of proxies in Afghanistan?}

Iran will have little problem in recruiting Afghans based in Iran for its proxies given their socio-economic plight. But considering the biting US sanctions and its impact on the Iranian economy, and the fall in oil and gas prices (due to global slump in demand because of COVID-19), Iran's coffers have been strained substantially. Oil prices fell to around US\$20-25 per barrel in May-July 2020 and are expected to remain low until the global economy recovers from the worst economic crisis since the 'great depression' in the 1930s. Iran's ability to support protracted proxy wars has been substantially affected due to economic problems and prolonged expensive conflicts in Iraq, Syria and Yemen. This will limit Iran's ability to project power in the Middle East and beyond. There are already calls within Iran to reduce or completely stop funding Hezbollah and Palestine, and use the resources for the Iranian people (Juneau 2020; Jay 2019). Iran is also wary of the huge influx of refugees into the country if it intervenes in Afghanistan which will put further pressure on Iran's weak economy. It will lead to an increase in violence in the restive provinces in eastern Iran and also increase socio-economic tensions between the refugees and Iranian citizens.

The problem has been further compounded by the spread of COVID-19 in Iran. Iran has emerged as the epicenter for COVID-19 in the Middle East. It has the highest number of infections and death toll in the region due to the government's botched response in tackling the pandemic. Concerns have been raised regarding the government's decision to remove COVID controls. The government was forced to remove restrictions because of the sagging economy. Valuable scarce resources need to be utilized to combat COVID-19 in Iran. This will put huge constraints on Iran's ability to use scarce resources for supporting its proxies in the wider region.

Experts interviewed by the author are of the opinion that Iran will not compromise on its national security interests in Afghanistan. It will use proxies to protect its interests. Economic sanctions and hardships did not prevent Iran from arming militias in Iraq and Syria to achieve its interests. Some of the experts are also of the opinion that Iran's expenditure on proxies is low (and effective) especially compared to Saudi Arabia as evidenced in Yemen. According to Mohsen Shariatinia, "Peace

38 Personal Communication 16 February 2021, Zoom.

39 Personal communication 17 February 2021, Zoom. 
and security in Afghanistan and preserving the Kabul government is a national security priority for Iran. Iran has enough financial and economic resources to support its forces in Afghanistan". 40

\section{Conclusion}

There is a broad consensus that the US-Taliban peace deal is most likely to fail. The withdrawal of the US and NATO troops, continued insurgency and ensuing violence, political instability and persecution of Shia Muslims and Hazaras in Afghanistan, and deterioration of US-Iran ties undermine Iran's interests in Afghanistan and the wider region. This provides Iran with incentives to become a potential spoiler by intervening in Afghanistan to secure its interests, exacerbate violence which may lead to civil war in Afghanistan with regional powers supporting different factions along ethnic and sectarian lines. Most likely it will remain a limited spoiler but can also rise up the spectrum to become a greedy spoiler in the event of Taliban trying to establish or establishing an Islamic Emirate in Afghanistan.

Iran's foreign policy is dictated by its interests, not by lack of cash. If Iran uses its proxies to secure its interests in Afghanistan contingent on the Taliban trying to establish or establishing an Islamic Emirate or dominating the national unity government (with unabated persecution of Shia and Hazara) in Afghanistan, it will increase tensions in Iran and may also threaten regime sustainability and survival given Iran's economic woes. But considering the geopolitical and religious rivalry with Saudi Arabia in the Islamic world, and its multi-faceted interests in Afghanistan, it is most likely to utilize its scarce political, diplomatic and economic resources to pursue foreign policy goals in Afghanistan and the broader region but at a high domestic cost.

\section{Declarations}

Conflict of interest The author states that there is no conflict of interest.

\section{References}

Afghan Voice Agency. n.d. Iran Declines Invitation to Afghanistan Meeting Involving US. https:// www.avapress.com/en/news/194770/iran-declines-invitation-to-afghanistan-meeting-involvingus. Accessed 13 May 2020.

Adili, A. Y. and M. van Bijlert. 2018. Taleban Attacks on Khas Uruzgan, Jaghori and Malestan (II): A new and violent push into Hazara areas. Afghanistan Analysis Network, 29 November. https:// www.afghanistan-analysts.org/en/reports/war-and-peace/taleban-attacks-on-khas-uruzgan-jagho ri-and-malestan-ii-a-new-and-violent-push-into-hazara-areas/. Accessed 15 May 2020.

Ahmed, A. (2020) Pakistan Army Chief Calls on Iran to Observe Principles of 'Non- interference and Equality.' Gulf News, 13 May.

${ }^{40}$ Personal communication 16 February 2021. Zoom. 
Akbarzadeh, S. 2015. Iran and the Shanghai Cooperation Organization: Ideology and Realpolitik in Iranian Foreign Policy. Australian Journal of International Affairs (AJIA) 69 (1): 88-103.

Akbarzadeh, S., and N. Ibrahimi. 2020. The Taliban: A new proxy for Iran in Afghanistan? Third World Quarterly 41 (5): 764-782.

Alfoneh, A. 2018. Tehran's Shia Foreign Legions, Carnegie Endowment for International Peace, 30 January. https://carnegieendowment.org/2018/01/30/tehran-s-shia-foreign-legions-pub-75387. Accessed 16 May 2020.

Ali, S. 2020. The specter of hate and intolerance: Sectarian-Jihadi nexus and the persecution of Hazara Shia community in Pakistan. Contemporary South Asia. Online First Publication. https://doi.org/10. 1080/09584935.2020.1855114.

Alizada, B. 2019. What peace means for Afghanistan's Hazara people. Aljazeera, 18 September.

Aljazeera. 2021. Hazaras fear for future as Afghanistan risks slipping into chaos. 3 February.

Allen, J. R. 2020. The US-Taliban peace deal: A road to nowhere. Brookings, 5 March, https://www. brookings.edu/blog/order-from-chaos/2020/03/05/the-us-taliban-peace-deal-a-road-to-nowhere/, accessed 15 May 2020;

Ashrafi, N. 2018. Three Afghans among top scorers at Iranian universities. Tolo News, 5 June.

Barton, J. 2020. U.S.-Taliban deal aimed to promote peace raises prospect of Taliban takeover. CGTN, 9 March.

Barzegar, K. 2014. Iran's Foreign Policy in Post-Taliban Afghanistan. The Washington Quarterly 37 (2): 119-137.

Basit, S. 2018. Explaining the impact of militancy on Iran-Pakistan relations. Small Wars \& Insurgencies 29 (5-6): 1040-1064.

Bezhan, F. 2018. Afghan Taliban Wants What It Hasn't Been Able To Hold: Hazara Regions. RFERL, 13 November.

Bezhan, F. 2020. The Return Of Pro-Iranian Militia Fighters To Afghanistan Fuels Fears In Kabul, Washington. RFERL, 7 February.

Bhatia, N. 2020. Iran's assertiveness post US-Taliban peace agreement reason for its criticism of India. Financial Express, 7 March.

CFR. 2019. A Conversation With Prime Minister Imran Khan of Pakistan, 23 September, https://www. cfr.org/event/conversation-prime-minister-imran-khan-pakistan-0. Accessed 15 May 2020.

Clarke, C. P, and A. Tabatabai. 2020. What Will Iran Do As the US Negotiates a Withdrawal from Afghanistan?" Defense One, 6 April.

Comments, Strategic. 2019. Afghanistan's Prospects 25 (10): i-iii.

Destradi, S. 2015. Difficulties of Regional Cooperation for Afghanistan: An Alternative Interpretation. Strategic Analysis 39 (2): 123-140.

Dozier, K. 2020. A U.S. Plane Crashed in Afghanistan. Why So Many Believed a CIA Chief Was On It. Time, 31 January.

Fair, C.C. 2014. Fighting to the End: The Pakistan Army's Way of War. New York: Oxford University Press.

Felbab-Brown, V. 2020. What's in store after the US-Taliban deal. Brookings, 4 March. https://www. brookings.edu/blog/order-from-chaos/2020/03/04/whats-in-store-after-the-us-taliban-deal/. Accessed 15 May 2020.

Filkins, D. 2010. Iran Is Said to Give Top Karzai Aide Cash by the Bagful. New York Times, 23 October.

Gandhara. 2017. Pakistan Bans Shi'ite Group For Syria War Recruiting. 31 January.

Gannon, K. 2019. Afghans recruited to fight in Syrian war struggle back home. AP News, 1 April.

Ghattas, K. 2020. Saudi Arabia, Iran, and the forty-year, rivalry that unraveled, culture, religion, and collective memory in the middle east. New York: Henry Holt and Co.

Hamidi, M. 2019. The Two Faces of the Fatemiyun (I): Revisiting the male fighters. Afghan Analyst Network, 8 July, https://www.afghanistan-analysts.org/en/reports/regional-relations/the-two-facesof-the-fatemiyun-i-revisiting-the-male-fighters/. Accessed 16 May 2020.

Hardy, R. 2010. Profile: Iran's Jundullah militants. BBC, 20 June.

Hiro, D. 2018. Cold War in the Islamic World: Saudi Arabia, Iran and the struggle for supremacy. New York: Oxford University Press.

Ibrahimi, N., and S. Akbarzadeh. 2020. Intra-Jihadist Conflict and Cooperation: Islamic State-Khorasan Province and the Taliban in Afghanistan. Studies in Conflict \& Terrorism 43 (12): 1086-1107.

Jamal, A. S. 2019. The Fatemiyoun Army: Reintegration into Afghan Society, United States Institute of Peace, Special Report No. 443, March. https://www.usip.org/sites/default/files/2019-03/sr_443-the_ fatemiyoun_army_reintegration_into_afghan_society-pdf_0.pdf. Accessed 16 May 2020. 
Jay, M. 2019. Iran crisis may make Trump look like Lord of War. But can he take the blowback? Middle East Online, 2 December.

Juneau, T. 2020. Iran's costly intervention in Syria: A pyrrhic victory. Mediterranean Politics 25 (1): $26-44$.

Katzman, K. 2020. Iran's Foreign and Defense Policies. Congressional Research Service, R44017, 29April. https://fas.org/sgp/crs/mideast/R44017.pdf. Accessed 10 May 2020.

Kube, C. and C. E. Lee. 2019. Trump wants to pull all U.S. troops out of Afghanistan by 2020 election, officials say. NBC News, 3 August.

Kumar, R. 2020. Taliban attempts to woo Afghanistan's Hazara community with new appointment. $N$ World, 28 April.

Kutty, S.N. 2014. Iran's Continuing Interests in Afghanistan. The Washington Quarterly 37 (2): 139-156.

Marcus, J. 2020. US-Iran war of words raises fresh fears of Gulf clash. BBC, 24 April

Mashal, M. 2020. As Iran and U.S. Trade Blows, Afghanistan Sweats Between the 2 Powers. The New York Times, 8 January.

Mashal, M. and F. Faizi. 2017. Iran Sent Them to Syria. Now Afghan Fighters Are a Worry at Home. The New York Times, 11 November.

Mehsud, R. 2020. Afghan Taliban look for support of Hazaras whom they once persecuted. Arab News, 7 May.

Middle East Online. 2020. Iran rejects peace agreement between US, Taliban. 1 March.

Milani, M. n.d. Iran and Afghanistan. https://iranprimer.usip.org/sites/default/files/Iran\%20and\%20Afg hanistan.pdf. Accessed 10 May 2020.

Motwani, N., and S. Srinjoy Bose. 2015. Afghanistan: 'spoilers' in the regional security context. AJIA 69 (2): 266-284.

RFERL. 2019. Pakistan Says Iran-Based Group Behind Deadly Attack. 20 April.

Regencia, T. 2019. Iran warns Pakistan to crack down on Jaish al-Adl. Aljazeera, 16 February.

Rehman, Z. U. 2014. The Baluch insurgency: linking Iran to Pakistan. Norwegian Peacebuilding Resource Centre, May. https://www.files.ethz.ch/isn/180927/31c68a20991b5a98b0dece4fd929c9c8. pdf. Accessed 12 May 2020.

Reuters. 2020. Iran dismisses U.S.-Taliban agreement over Afghanistan. 1 March.

Riedel, B. 2020. The mess in Afghanistan, 4 March, Brookings. https://www.brookings.edu/blog/orderfrom-chaos/2020/03/04/the-mess-in-afghanistan/. Accessed 15 May 2020.

Samaan, J. 2018. The Fragile Decoupling of Regional Power Plays. Whitehall Papers 92 (1IV): 63-79.

Sawahel, W. 2017. Iran, Saudi Arabia vie for influence over Afghanistan. University World News, 15 December. https://www.universityworldnews.com/post.php?story=20171212141208319. Accessed 12 May 2020.

Shams, S. 2019. Pakistan blames Iran-based separatists for deadly Baluchistan attack. Deutsche Welle, 4 April.

Siddique, A. 2020. Are The Taliban Committed To Negotiating Peace In Afghanistan? Gandhara, 31 March.

Stedman, S.J. 1997. Spoiler Problems in Peace Processes. International Security 22 (2): 5-53.

Tarzi, N. 2020. US-Iranian competition over Iraq at dead end. Middle East Online, 23 March 23. https:// middle-east-online.com/en/us-iranian-competition-over-iraq-dead-end. Accessed 12 May 2020.

Tehran Times. 2020. Police seize over 1.5 tons of drugs in Southeastern Iran. 10 March.

The Financial Tribune. 2018. Iran Biggest Trade Partner of Afghanistan in 2017-18. 8 April.

The Express Tribune (2014) Jundullah vows allegiance to Islamic State. 18 November.

Therme, C. 2017. The Shi'a Afghan Community: Between Transnational Links and Internal Hurdles. Iranian Studies 50 (4): 511-521.

UNHCR. n.d. Refugees in Iran, https://www.unhcr.org/ir/refugees-in-iran/. Accessed 10 May 2020.

Verma, R. 2020a. Domestic Political Drivers and Chinese Diplomacy: Xinjiang and Counter-Terrorism in South Asia. Asian Perspective 44 (4): 561-586.

Verma, R. 2020b. The US-Taliban peace deal and India's strategic options. Australian Journal of International Affairs 75 (1): 10-14.

Zucchino, D. and F. Faizi. 2019. They Are Thriving After Years of Persecution but Fear a Taliban Deal. The New York Times, 27 March.

Publisher's Note Springer Nature remains neutral with regard to jurisdictional claims in published maps and institutional affiliations. 